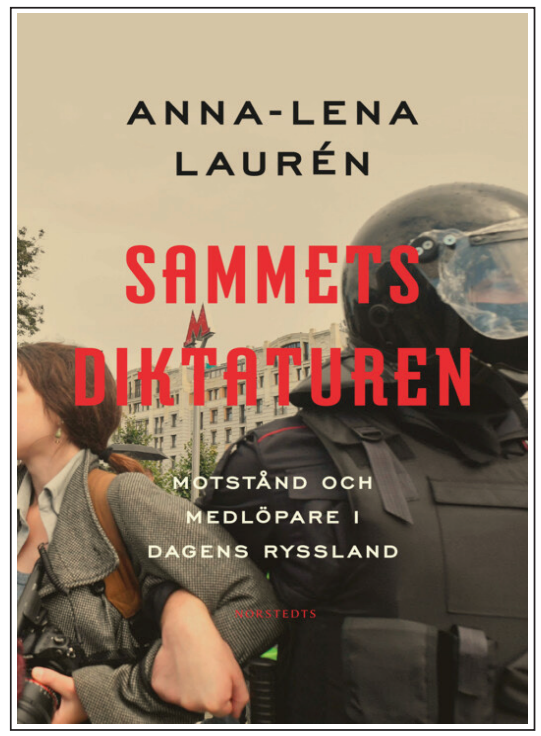

\title{
Sammetsdiktaturen. Motstånd och medlöpare i dagens Ryssland
}

\author{
Anna-Lena Laurén \\ Stockholm: Norsteds 2021 \\ 185 sider. ISBN 9789523333673
}

Omtalt av Evgeniya Khoroltseva [jobber med menneskerettighetsundervisning i Menneskerettighetsakademiet, eugenia@mr-akademiet.no]

Sammetsdiktaturen: Motstånd och medlöpare $i$ dagens Ryssland er skrevet av den finlandssvenske journalisten Anna-Lena Laurén, som har bodd i Russland de siste 15 årene. Tittelen, som kan oversettes til Fløyelsdiktatur på norsk, er kanskje ikke så fengende og innlysende som tittelen på den første boka hennes: De er ikke riktig kloke, de russerne. Innholdet er derimot mer variert og spennende. Laurén går et steg videre i sin skildring av det politiske Russland og sitt eget journalistiske virke, i et land som er på randen til å bli et diktatur. I Russland bruker myndighetene «knyttneven» når de mener at det trengs, men tar på «fløyelshansken» når det tjener dem best. Det politiske livet er nøye regissert, men hundre prosent under kontroll kan det vel aldri være?

Lauréns valg om å ikke bare skildre det russiske samfunnet og kulturen, men også utviklingen av russisk politikk, samtidig som hun jobber som korrespondent for en utenlandsk medieinstitusjon, er modig. Det er alltid en fare for å falle i unåde hos russiske myndigheter og miste akkreditering eller visum. Ytterst få utenlandske journalister drister seg til å skrive en hel bok om dagens politiske situasjon i landet. Vi snakker tross alt om et autoritært politisk regime som etter alt å dømme kommer til å bli stadig mer hardhendt.

Russland har de siste ti årene vært preget av kraftfulle og folkerike sivile protester. Laurén skildrer flere av dem: demonstrasjonen på Bolotnaja-plassen i Moskva i 2011, traktormarsjen sør i Russland i 2016, og de pågående protestene (2021) i byen Sjies i Arkhangelsk-regionen og i Khabarovsk, langt øst i landet. Russland har et høyt antall samvittighetsfanger, og over 400 mennesker sitter i fengsel utelukkende for sin 
politiske overbevisning. Forfølgelser er ikke bare forbeholdt journalister og aktivister. Alle som har ideer, kan bli forfulgt. Motstanden tiltar i takt med at Putin-regimet hardner grepet. Laurén bruker uttrykket «Putin-regimet» mye. Med tanke på hvor stor makt president Putin har, er dette en riktig betegnelse. Politiske motstandere ikke bare fengsles og undertrykkes, drap benyttes også for å uskadeliggjøre dem, slik som drapet på Boris Nemtsov i 2015 og drapsforsøket på Aleksej Navalnyj i 2020 med nervegiften novitsjok.

Det tærer på å rapportere fra et land med så utbredt undertrykking. For Laurén blir løsningen å avdekke et annet Russland, ved å dra til perifere steder som det ikke skrives så mye om ellers. Slik ble interessen og engasjementet hennes for rettssaken mot Jurij Dmitrijev skapt. Den 65-årige aktivisten fra Karelia har brukt mesteparten av sitt voksne liv på å avdekke massegraver og gi navn til drepte under Stalinregimet. Aktivisten har vært gjennom lange rettssaker og soner nå en dom på 13 år. Putins Russland er ikke interessert i å lære om de mørke sidene ved landets historie.

Innimellom fletter Laurén inn scener fra sin egen hverdag i Russland som kan forklare væremåter ansett som normale i det russiske samfunn, for deretter å trekke paralleller til hva som er normalt i politisk forstand. Boka er full av morsomme og til tider absurde dialoger fra busser, treningssentre og fester. Hun nevner syv måter å bruke ordet njet på, og skriver mye om litteraturens betydning for den jevne russer. Det absurde går imidlertid fort over i det alvorlige: Stalins økende popularitet, fortielse av historiske ugjerninger og patriarkalske holdninger til kvinner.

På flere måter kan man si at ting er snudd opp ned i Russland. Mens man i Vesten lurte på hvordan man skulle forholde seg til tidligere president Donald Trump og hans åpenbare løgner, har Trump i Russland vært dyrket som en å se opp til. Laurén påpeker videre at det ikke er Russland som nærmer seg Vesten, men omvendt. Sterkere tendenser til relativisering og utvasking av liberale verdier iVesten bidrar til økende populistisk retorikk og forvitring av demokratiet.

En god del av boka er dedikert til drøfting av det russiske medielandskapet og dets rolle for politikk og samfunn. Russland kan virke som et sted der tåkeprat nærmest er en dyd. Tåkepraten rommer alt fra bortforklaringer og tulleprat til løgn, propaganda og populisme. Russernes kjærlighet for drama og skuespill bidrar i en viss grad til at også politikken gjøres om til et skuespill. Informasjonskrig har blitt Kremls våpen for å blande kortene og skape forvirring. TV-kanalen Russia Today (RT) er mektig, og får stor finansiell støtte fra staten. Både russiske og utenlanske journalister, men særlig de sistnevnte, må hele tiden være på vakt mot å gjengi informasjon som er manipulert. Flere steder i boka prøver Laurén å forstå Kremls strategi om å lyve til verden. Ville det ikke være lettere for Russland å si det rett ut i stedet for å lyve og tåkelegge, undres hun:Vi er en stormakt og gjør dermed ting dere ikke liker, fordi det passer oss (for eksempel annekteringen av Krim-halvøya og nedskytningen av passasjerflyet MH17 over Ukraina).

Kommunikasjonsmønstrene $\mathrm{i}$ det daglige liv, hvor fortielse og forvrenging av informasjon er vanlig, projiseres på det politiske styret i Russland: Alle vet at 


\section{8 | EVGENIYA KHOROLTSEVA}

makthavende lyver - hva så? Hvorfor lage bråk om det? Alle vet at makthavende stjeler fra statskassa og kjøper luksuriøse villaer i utlandet - hva så? Det er flere spørsmål enn svar. Og er man ute etter å få innblikk i hvordan Russland henger sammen, hva politikere finner på for å beholde makten og hvordan det er å jobbe der som utenlandsk journalist, har denne boka mye å by på. Boka kan anbefales til alle som ønsker å trenge dypere inn i russisk kultur og samfunn. 